\title{
Association of Poly(Adenosine Diphosphoribose) Synthesis with DNA Damage and Repair in Normal Human Lymphocytes
}

\author{
Nathan A. Berger, Georgina W. Sikorski, Shirley J. Petzold, and \\ KeVIN K. KuROHARA, Division of Hematology-Oncology, Department of Medicine, \\ Washington University School of Medicine at The Jewish Hospital of St. Louis, \\ St. Louis, Missouri 63110
}

\begin{abstract}
A B S T R A C T A permeable cell technique was used to measure the alterations in synthesis of DNA and poly(adenosine diphosphoribose) in normal human lymphocytes after treatment of the cells with different types of DNA-damaging agents. The lymphocytes showed an abrupt increase in the unscheduled synthesis of DNA and poly(adenosine diphosphoribose) in response to ultraviolet (UV) irradiation. The increases were apparent within $1 \mathrm{~h}$ and reached a maximum between 2 and $4 \mathrm{~h}$ after irradiation. The magnitude of the increases in DNA and poly(adenosine diphosphoribose) synthesis was dependent upon the UV dose. Alkaline $\mathrm{CsCl}$ gradient studies, with bromodeoxyuridine triphosphate density labeling of DNA, demonstrated that the unscheduled DNA synthesis, which occurred in response to UV irradiation, was actually a result of the repair mode of DNA synthesis. Similar increases in DNA synthesis, and poly(adenosine diphosphoribose) synthesis occurred when lymphocytes were treated with several other DNA-damaging agents, including bleomycin, $N$-methyl- $N^{\prime}$-nitro- $N$-nitrosoguanidine or $N$-acetoxyacetyl aminofluorene. Treatment of lymphocytes with DNase, under conditions which allowed degradation of cellular DNA, also resulted in increased synthesis of poly(adenosine diphosphoribose). Cycloheximide did not inhibit the increase in synthesis of DNA or poly(adenosine diphosphoribose) that occurred in response to treatment with the DNA-damaging agents.
\end{abstract}

\section{INTRODUCTION}

Poly(adenosine diphosphoribose) (ADPR) ${ }^{1}$ polymerase is a tightly bound chromosomal enzyme that uses the

Dr. Berger is a Leukemia Society of America Scholar.

Received for publication 11 December 1978 and in revised form 6 February 1979.

${ }^{1}$ Abbreviations used in this paper: ADPR, adenosine di-
ADPR moiety derived from $\mathrm{NAD}^{+}$to synthesize the homopolymer, poly(ADPR) $(1,2)$. The activity of this enzyme appears to increase when cells are treated with DNA-damaging agents such as endonucleases, $\gamma$-radiation, bleomycin, and $N$-methyl- $N$ '-nitro- $N$-nitrosoguanidine (3-8). This association with DNA-damaging agents has led to the suggestion that poly(ADPR) synthesis may be involved in the process of DNA repair (3-9), however, an association with DNA repair has never been demonstrated. Because DNA damage induced by ultraviolet (UV) irradiation and the processes involved in its repair are different from those associated with the agents noted above $(10,11)$, it was of interest to determine whether poly(ADPR) synthesis responded to UV irradiation in normal cells and, if so, whether it was associated with DNA repair synthesis. These studies were conducted with normal human lymphocytes which were rendered permeable to exogenously supplied nucleotides to facilitate studies of the synthesis of DNA and poly(ADPR) (12). These permeable cell preparations allow us to supply the desired radioactive- or density-labeled nucleotides to the enzymes in the nucleus and effectively bypass the problems associated with nucleoside uptake and intracellular pool sizes. The usefulness of this preparation to measure synthesis of DNA and poly(ADPR) has been demonstrated previously $(4,12,13)$.

\section{METHODS}

Cell preparation, culture, and treatment. Blood was obtained from fasting, normal human donors who were taking no drugs. The blood was defibrinated, and lymphocytes were

phosphoribose; BrdUTP, bromodeoxyuridine triphosphate; CHO, Chinese hamster ovary; dTMP, deoxythymidine monophosphate; dThd, deoxythymidine; dTTP, deoxythymidine triphosphate; PBS, phosphate-buffered saline; PHA, phytohemagglutinin; UV, ultraviolet. 
isolated on Ficoll- (Sigma Chemical Co., St. Louis, Mo.) Hypaque (Winthrop Laboratories, New York) gradients (12, 14). Purified lymphocytes were suspended at a final concentration of $2 \times 10^{6}$ cells $/ \mathrm{ml}$ in $\alpha$-modified Eagle's medium supplemented with $10 \%$ heat-inactivated fetal calf serum, 50 $\mathrm{U} / \mathrm{ml}$ penicillin, $50 \mu \mathrm{g} / \mathrm{ml}$ streptomycin, and $25 \mathrm{mM}$ Hepes buffered to a final $\mathrm{pH}$ of 7.2 , and then incubated at $37^{\circ} \mathrm{C}$. For mitogen stimulation, $20-\mathrm{ml}$ aliquots of cell suspension were grown in 75-cm tissue culture flasks to which leukoagglutinating phytohemagglutinin (PHA) (15) was added at a final concentration of $1.7 \mu \mathrm{g} / \mathrm{ml}$.

For UV irradiation, cells were removed from the medium by centrifugation at $800 \mathrm{~g}$ for $5 \mathrm{~min}$ at room temperature and resuspended at $2 \times 10^{6} \mathrm{cells} / \mathrm{ml}$ in phosphate-buffered saline (PBS) ( $10 \mathrm{~g} \mathrm{NaCl}, 250 \mathrm{mg} \mathrm{KCl}, 3.6 \mathrm{~g} \mathrm{Na} \mathrm{HPO}_{4} \cdot 7 \mathrm{H}_{2} \mathrm{O}$, and $250 \mathrm{mg} \mathrm{KH} \mathrm{PO}_{4} /$ liter, $\mathrm{pH} 7.5$ ). 10-ml aliquots of this cell suspension were spread in 150 -mm diameter, plastic Petri dishes and irradiated with a General Electric 15 W Germidical Lamp, G15T8 (General Electric Co., Schenectady, N. Y.) (principle radiation, $2,537 \AA$ ) at an incident dose rate of $1 \mathrm{~J} / \mathrm{m}^{2}$ per s as calibrated with a J-225, Black-Ray, UV Meter (Ultra-Violet Products, Inc., San Gabriel, Calif.). After irradiation, cells were washed from the plates, medium was added to the suspension, and the cells were collected by centrifugation at $800 \mathrm{~g}$ for $5 \mathrm{~min}$ at room temperature and resuspended in the $\alpha$-modified Eagle's medium with $10 \%$ serum at $2 \times 10^{6}$ cells $/ \mathrm{ml}$ and then incubated at $37^{\circ} \mathrm{C}$. During the entire UV irradiation procedure, cells were out of the $37^{\circ} \mathrm{C}$-incubator for a total of 15 min. The time of UV irradiation was taken as the 0 time. Approximately $7 \mathrm{~min}$ passed from this point until cells were returned to incubation at $37^{\circ} \mathrm{C}$ in complete medium. In several experiments, control, unirradiated cells were subjected to the same procedures of centrifugation, resuspension in PBS, and spreading on Petri dishes. This treatment had no effect on the levels of DNA or poly(ADPR) synthesis.

For experiments involving drug treatments, the agents were dissolved in appropriate solvents and immediately added to the lymphocyte suspension. Bleomycin (Bristol Laboratories, Div. Bristol-Myers Co., Syracuse, N. Y.) was dissolved in PBS. $\mathrm{N}$-acetoxy-acetyl aminofluorene (furnished by the Carcinogen Chemical Repository operated at IIT Research Institute, Chicago, Ill. for the National Cancer Institute and the Division of Cancer Cause and Prevention) and $N$-methyl- $N^{\prime}$-nitro- $N$ nitrosoguanidine were dissolved in dimethyl sulfoxide and added to lymphocyte suspensions. Dimethyl sulfoxide was present at a final concentration of $2 \%$; control studies demonstrated that the presence of $2 \%$ dimethyl sulfoxide did not affect synthesis of DNA or poly(ADPR) during the time-course of these studies. Cycloheximide, when used, was added just before addition of the DNA-damaging agents or as soon as the UV-irradiated cells were returned to complete medium, which was $7 \mathrm{~min}$ after irradiation.

For measurements of protein synthesis, control or UV-irradiated cells were collected immediately after treatment by centrifugation at $800 \mathrm{~g}$ for $5 \mathrm{~min}$ at room temperature and resuspended at $1 \times 10^{6} \mathrm{cells} / \mathrm{ml}$ in leucine-deficient, Eagle's minimum essential medium (Gibco, Grand Island, N. Y.) supplemented with $2 \%$ glutamine, $10 \%$ dialysed fetal calf serum, $50 \mathrm{U} / \mathrm{ml}$ penicillin, and $50 \mu \mathrm{g} / \mathrm{ml}$ streptomycin. 2-ml aliquots of cells were then incubated in the presence of $\mathrm{L}-\left[4,5-{ }^{3} \mathrm{H}\right]$ leucine, $25 \mu \mathrm{Ci} / \mathrm{ml}(105 \mathrm{Ci} / \mathrm{mmol}$ sp act) (Amersham/Searle Corp., Arlington Heights, Ill.), with and without cycloheximide at final concentrations of 50 and $100 \mu \mathrm{g} / \mathrm{ml}$. After $3 \mathrm{~h}$ at $37^{\circ} \mathrm{C}$, cells were diluted with $7 \mathrm{ml}$, ice-cold, $0.9 \% \mathrm{NaCl}$ and collected by centrifugation at $2,200 \mathrm{~g}$ at $4^{\circ} \mathrm{C}$ for $10 \mathrm{~min}$. The washed cells were precipitated with $20 \%$ TCA, collected on Whatman GF/C discs (Whatman, Inc., Clifton, N. J.), and washed an additional five times with
$20 \%$ TCA. Radioactivity on the discs was determined in a toluene-based scintillation fluids as previously described (4). All reactions were performed in triplicate.

Cell permeabilization and measurements of nucleic acid synthesis. Synthesis of DNA and poly(ADPR) was measured after the cells were rendered permeable to exogenously supplied nucleotides. Details of this technique, the proof that the cells become permeable to exogenously supplied phosphorylated compounds, the proof that the reaction products are distinctly DNA or poly(ADPR), and the kinetics of each reaction have already been presented in detail $(4,12,13,16)$. In principle, cells are rendered permeable to exogenously supplied nucleotides by a cold shock in a hypotonic buffer composed of $0.01 \mathrm{M}$ Tris/ $\mathrm{HCl}, \mathrm{pH} \mathrm{7.8,1} \mathrm{mM}$ EDTA, $4 \mathrm{mM}$ $\mathrm{MgCl}_{2}$, and $30 \mathrm{mM}$ 2-mercaptoethanol. The permeabilized cells are finally resuspended in this buffer at $2 \times 10^{7}$ cells $/ \mathrm{ml}$, and $50 \mu \mathrm{l}$ of the cell suspension is combined with $25 \mu \mathrm{l}$ of reaction mix for DNA synthesis or poly(ADPR) synthesis. The final concentration of components in the system to measure DNA synthesis is $6.6 \mathrm{mM}$ Tris/ $\mathrm{HCl}, \mathrm{pH} \mathrm{7.8,20} \mathrm{mM}$ mercaptoethanol, $0.66 \mathrm{mM}$ EDTA, $9.3 \mathrm{mM} \mathrm{MgCl}_{2}, 70 \mathrm{mM} \mathrm{NaCl}, 33$ $\mathrm{mM}$ Hepes, pH 7.8, $5 \mathrm{mM}$ ATP, $0.1 \mathrm{mM}$ deoxyATP, $0.1 \mathrm{mM}$ deoxyguanosine triphosphate, $0.1 \mathrm{mM}$ deoxycytidine triphosphate, and $0.26 \mu \mathrm{M}\left[{ }^{3} \mathrm{H}\right]$ deoxythymidine triphosphate (dTTP) $\left(140 \times 10^{6} \mathrm{dpm} / \mathrm{nmol} \mathrm{sp}\right.$ act $)$ and $1 \times 10^{6}$ permeabilized cells. For density-shift experiments the reaction system contained $0.1 \mathrm{mM}$ bromodeoxyuridine triphosphate (BrdUTP) and 4.6 $\mu \mathrm{M}\left[{ }^{3} \mathrm{H}\right] \mathrm{dTTP}\left(63 \times 10^{6} \mathrm{dpm} / \mathrm{nmol} \mathrm{sp}\right.$ act $)$ in addition to the other components listed above. The ratio of BrdUTP to $\left[{ }^{3} \mathrm{H}\right]-$ dTTP in the latter reaction mix is 21 , thus 21 molecules of bromodeoxyuridine monophosphate should be incorporated into DNA for every molecule of $\left[{ }^{3} \mathrm{H}\right]$ deoxythymidine monophosphate (dTMP).

The final concentration of components in the reaction system to measure poly(ADPR) synthesis is $33 \mathrm{mM}$ Tris/ $\mathrm{HCl}, \mathrm{pH}$ 7.8, $20 \mathrm{mM}$ mercaptoethanol, $0.66 \mathrm{mM}$ EDTA, $42.5 \mathrm{mM}$ $\mathrm{MgCl}_{2}$, and $0.33 \mathrm{mM}\left[{ }^{3} \mathrm{H}\right] \mathrm{NAD}^{+}$[adenine-2,8- $\left.{ }^{3} \mathrm{H}\right]\left(24 \times 10^{3}\right.$ $\mathrm{dpm} / \mathrm{nmol}$ sp act) and $1 \times 10^{6}$ permeabilized cells. Each component of this reaction system is present at concentrations that were previously determined to be optimal for this system $(4,12)$. To measure DNase-responsive poly(ADPR) synthesis, the reaction system was adjusted to contain $0.05 \%$ Triton X-100 (Sigma Chemical Co.) and $30 \mu \mathrm{g}$ of DNase I for a final concentration of $300 \mu \mathrm{g} / \mathrm{ml}$. This concentration of DNase has been previously demonstrated to produce maximal stimulation of poly(ADPR) synthesis $(4,12)$.

To measure DNA synthesis, reaction tubes were incubated at $37^{\circ} \mathrm{C}$ for $30 \mathrm{~min}$; to measure poly(ADPR) synthesis, reaction tubes were incubated at $30^{\circ} \mathrm{C}$ for $30 \mathrm{~min}$. DNA-synthesis reactions were terminated by precipitation with an excess of cold, $10 \%$ TCA with $2 \% \mathrm{Na}_{4} \mathrm{P}_{2} \mathrm{O}_{7}$. Poly(ADPR)-synthesis reactions were terminated with an excess of cold, $20 \%$ TCA. Samples were sonicated, collected on Whatman GF/C filter discs, and washed five times with $10 \%$ TCA with $2 \%$ $\mathrm{Na}_{4} \mathrm{P}_{2} \mathrm{O}_{7}$ in the case of DNA, or five times with $20 \%$ TCA in the case of poly(ADPR). All discs were washed twice with ethanol; then the radioactivity was determined in a toluenebased scintillation fluid as previously described (4). All reactions were performed in triplicate.

Isopycnic gradient. On the 3rd d in culture, PHA-stimulated lymphocytes were incubated in the presence of $1 \mu \mathrm{Ci} / \mathrm{ml}$ [methyl $-{ }^{14} \mathrm{C}$ ]deoxythymidine (dThd) $(49 \mu \mathrm{Ci} / \mathrm{nmol} \mathrm{sp}$ act) for $18 \mathrm{~h}$ to label parental density DNA. Aliquots containing $1 \times 10^{6}$ cells were collected by centrifugation at $2,000 \mathrm{~g}$, washed with $0.1 \mathrm{M} \mathrm{NaCl}, 10 \mathrm{mM}$ EDTA, $10 \mathrm{mM}$ Tris/HCl, pH 8, and stored frozen. For density-labeling experiments, control, UV-irradiated, or PHA-stimulated cells were incubated in $5 \mu \mathrm{g} / \mathrm{ml}$ bromodeoxyuridine for $90 \mathrm{~min}$ to density 
label the growing ends of any active replication forks, then the cells were permeabilized and incubated in the reaction mix containing BrdUTP and $\left[{ }^{3} \mathrm{H}\right] \mathrm{dTTP}$ for $30 \mathrm{~min}$ at $37^{\circ} \mathrm{C}$. The reactions were terminated by the addition of an excess of cold $0.1 \mathrm{M} \mathrm{NaCl}, 10 \mathrm{mM}$ EDTA, $10 \mathrm{mM}$ Tris/HCl pH 8 buffer, and the cells were collected by centrifugation at $2,000 \mathrm{~g}$ and stored frozen.

For alkaline $\mathrm{CsCl}$ gradients, aliquots of $1 \times 10^{6}$ cells labeled with $\left[{ }^{14} \mathrm{C}\right] \mathrm{dTh}$ were combined with $1 \times 10^{6}$ cells labeled with ${ }^{3} \mathrm{H}$ and BrdUTP in $4.3 \mathrm{ml}$ of $5 \mathrm{mM} \mathrm{NaCl}, 0.5$ mM EDTA, $0.5 \mathrm{mM}$ Tris/ $\mathrm{HCl}, \mathrm{pH} 8,1 \%$ sodium lauroyl sarcosine, sheared by 10 passes through a 26-gauge needle, and then treated overnight at $37^{\circ} \mathrm{C}$ with $90 \mu \mathrm{g} / \mathrm{ml}$ Proteinase $\mathrm{K}$. The solutions were adjusted to a $\mathrm{pH}$ above 12 by addition of $0.5 \mathrm{ml} 2 \mathrm{~N} \mathrm{NaOH}$. Solid $\mathrm{CsCl}$ was added to a refractive index of 1.4080 , then $6.5 \mathrm{ml}$ of the DNA solutions in alkaline $\mathrm{CsCl}$ were transferred to polyallomer tubes and centrifuged in a Beckman type $\mathbf{5 0}$ rotor (Beckman Instruments, Inc., Spinco Div., Palo Alto, Calif.) at $44,000 \mathrm{rpm}$ at $25^{\circ} \mathrm{C}$ for $40 \mathrm{~h}$ (16). Tubes were punctured, and 10 drop fractions were collected from the bottoms. Aliquots were taken to measure refractive index, and $100 \mu$ l of each fraction was spotted onto Whatman 3MM filter discs (Whatman, Inc.), which were washed and prepared for scintillation counting as previously described (16). Radioactivity was determined, and ${ }^{3} \mathrm{H}$ counts were corrected for ${ }^{14} \mathrm{C}$ crossover with the autoisotope program for dual-labeled samples on a Searle mark III liquid scintillation system (Searle Analytic, Inc., Des Plaines, Ill.). Samples that were processed and sheared in the identical fashion were also analyzed on $5-20 \%$, linear, alkaline sucrose gradients along with an internal standard of ${ }^{32} \mathrm{P}$-labeled $\lambda$ pLac $5 \mathrm{~S} 7$ DNA (16). The latter study showed that the average length of DNA sheared and processed under these conditions was 10-11 kilobases long.

\section{RESULTS}

Human peripheral blood lymphocytes from normal donors are resting, intermitotic cells that show low spontaneous levels of DNA and poly(ADPR) synthesis (12). When normal lymphocytes are stimulated with PHA, the rates of poly(ADPR) synthesis and replicative DNA synthesis remain low for $24 \mathrm{~h}$, then increase, reaching peak values during the $3 \mathrm{rd}$ and 4 th $\mathrm{d}$ in culture (12). Fig. 1 demonstrates that in freshly prepared lymphocytes, the synthesis of both DNA and poly(ADPR) increases abruptly in response to UV irradiation. Examination of these responses in several different experiments, with cells obtained from a number of donors, demonstrated that synthesis of DNA and poly(ADPR) increased within $1 \mathrm{~h}$ and reached peak values between 2 and $4 \mathrm{~h}$ after irradiation. We have also been able to demonstrate increases in DNA and poly(ADPR) synthesis at shorter time intervals after UV irradiation, but we have not yet been able to consistently demonstrate whether the increased synthesis of either polymer preceeds the other.

Fig. 2 presents a dose-response curve for the synthesis of DNA and poly(ADPR) that occurs in response to UV irradiation. At $2.5 \mathrm{~J} / \mathrm{m}^{2}$, the lowest dose examined, there were increases in both DNA synthesis and poly(ADPR) synthesis as compared with the levels in the

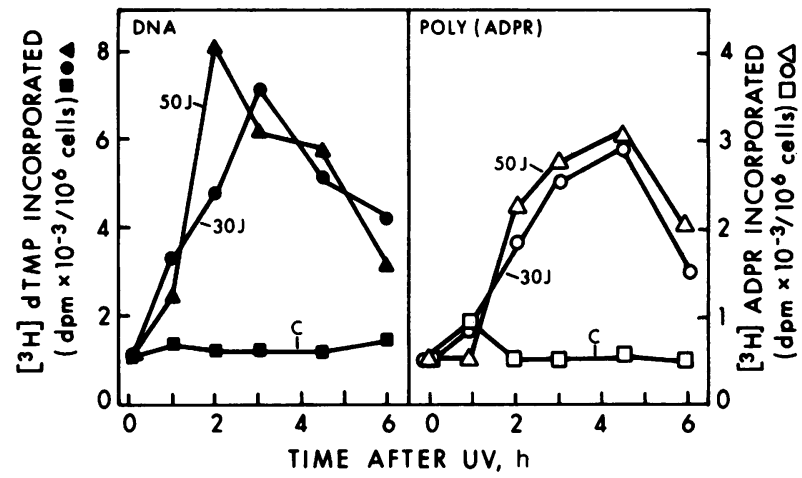

FIgURE 1 Time-course of DNA and poly(ADPR) synthesis in response to UV irradiation. Freshly isolated, normal, human lymphocytes were suspended in PBS at $2 \times 10^{6} \mathrm{cells} / \mathrm{ml}$ and mock irradiated in the case of control cells $(\square, \square)$ or irradiated with $30 \mathrm{~J} / \mathrm{m}^{2}(0,0)$ or $50 \mathrm{~J} / \mathrm{m}^{2}(\Delta, \Delta)$, then returned to incubation at $37^{\circ} \mathrm{C}$ in $\alpha$-modified Eagle's medium with $10 \%$ fetal calf serum as described in Methods. Time is expressed in hours after UV irradiation. At the time points indicated, cells were removed from culture, permeabilized, and used to measure synthesis of DNA (filled symbols) and poly(ADPR) (open symbols).

control, unirradiated cells. The synthetic rates of both polymers continued to increase in a dose-dependent fashion with the greatest increment in polymer synthesis occurring in the range from 0 to $20 \mathrm{~J} / \mathrm{m}^{2}$.

The unscheduled DNA synthesis (17) that occurred in the lymphocytes, after UV irradiation, appears to be DNA repair because it occurred too rapidly for the induction of replicative synthesis, which usually requires 2-3 d in PHA-stimulated normal lymphocytes $(12,18)$. To confirm the nature of the unscheduled DNA synthesis, we compared the DNA synthesized by UV-irradiated cells with the DNA synthesized by lympho-

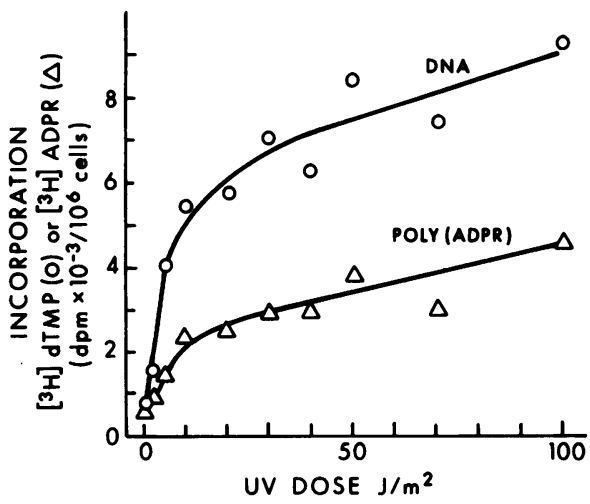

FIGURE 2 UV dose-response curve of DNA and poly(ADPR) synthesis. Freshly isolated, normal, human lymphocytes were suspended at $2 \times 10^{6} \mathrm{cells} / \mathrm{ml}$ in PBS and UV irradiated as described in Methods. Cells were resuspended in $\alpha$-modified Eagle's medium with $10 \%$ serum and incubated at $37^{\circ} \mathrm{C}$ for $3 \mathrm{~h}$. Control and all irradiated cells were then permeabilized and used to measure synthesis of DNA (O) or poly(ADPR) $(\Delta)$. 
cytes on the 3rd d after PHA stimulation. These experiments were performed by allowing DNA synthesis to progress in the presence of $0.1 \mathrm{mM} \mathrm{BrdUTP}$ as the density label, and $4.6 \mu \mathrm{M}\left[{ }^{3} \mathrm{H}\right] \mathrm{dTTP}$ as the radioactive label, and then analyzing the product on alkaline $\mathrm{CsCl}$ gradients. Under these conditions, replicative DNA synthesis should result in the production of long strands of newly synthesized DNA containing BrdUTP and $\left[{ }^{3} \mathrm{H}\right] \mathrm{dTTP}$ in the same ratio $(21: 1)$ as is present in the reaction mix. Because of the extensive substitution with bromodeoxyuridine monophosphate, the newly synthesized strands should sediment at much higher density than parental DNA. In contrast, when DNA is repaired by insertion of nucleotide patches into areas of DNA damage, then the random insertion of bromodeoxyuridine monophosphate should not cause significant changes in the density of the parental DNA (19).

Fig. 3A shows the alkaline $\mathrm{CsCl}$ gradient pattern of replicative DNA synthesis produced by the PHAstimulated cells. On the $3 \mathrm{rd} \mathrm{d}$ in culture, aliquots of the stimulated cells were incubated with $\left[{ }^{14} \mathrm{C}\right] \mathrm{dTh}$ to label the parental DNA. At the same time, other aliquots of PHA-stimulated cells were rendered permeable to exogenously supplied deoxynucleotides, then incubated in the reaction mix containing ATP, deoxyATP, deoxycytidine triphosphate, deoxyguanosine triphosphate, BrdUTP, and trace quantities of $\left[{ }^{3} \mathrm{H}\right] \mathrm{dTTP}$. The density of the parental DNA is shown by the ${ }^{14} \mathrm{C}$ label. Most of the ${ }^{3} \mathrm{H}$-labeled DNA synthesized in the presence of BrdUTP is shifted to high density, demonstrating that most of the DNA synthesized by the permeabilized PHA-stimulated cells was the product of semiconservative, replicative-type synthesis. Fig. 3B illustrates the pattern obtained when UV-irradiated cells were rendered permeable to deoxynucleotides and then incubated with the same BrdUTP-substituted reaction mix. Before applying them to the alkaline $\mathrm{CsCl}$ gradients, these cells were combined with aliquots of the cells that were stimulated with PHA and incubated in $\left[{ }^{14} \mathrm{C}\right] \mathrm{dTh}$ to label the parental DNA. In contrast to the results obtained with the PHA-stimulated cells, the DNA synthesized in the presence of BrdUTP by the UV-irradiated cells has the same buoyant density as the parental DNA, indicating that it is the product of DNA repair synthesis.

Lymphocytes were examined from a series of normal donors to determine whether an increase in poly(ADPR) synthesis consistently accompanied the DNA repair synthesis that occurred in response to UV irradiation. Table I shows that lymphocytes from 12 consecutive donors all responded to UV irradiation with an increase in synthesis of DNA and poly(ADPR). The data suggest that the amount of DNA synthesis may be proportional to the amount of poly(ADPR) synthesis, however, the series is still too small, and many more donors will have to be analyzed to firmly establish this relation.

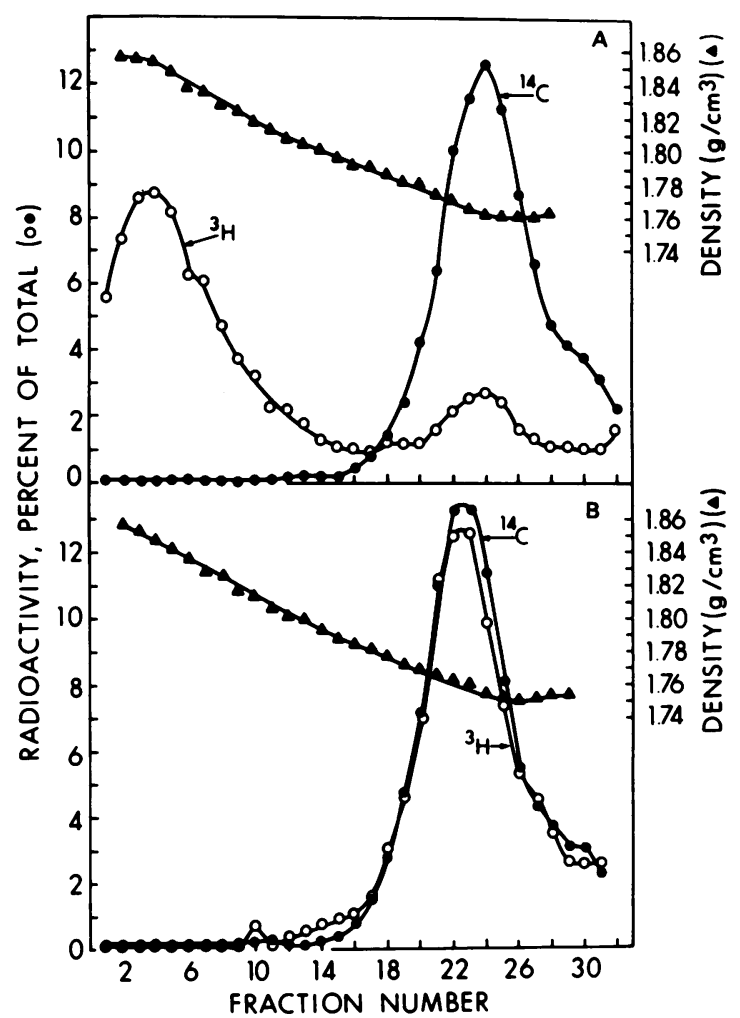

Figure 3 Alkaline $\mathrm{CsCl}$ density-gradient profile of DNA synthesized by (A) normal human lymphocytes after PHA stimulation or (B) UV irradiation. Lymphocytes from a normal donor were stimulated with PHA, and on the 3rd d in culture they were incubated for $18 \mathrm{~h}$ with $\left[{ }^{14} \mathrm{C}\right] \mathrm{d}$ Thd to prelabel parental density DNA. (A) PHA-stimulated lymphocytes were permeabilized and incubated for $30 \mathrm{~min}$ in the presence of a reaction mix containing BrdUTP and $\left[{ }^{3} \mathrm{H}\right] \mathrm{dTTP}$ as described in Methods. Cells containing the ${ }^{3} \mathrm{H}(\mathrm{O})$ and density label were combined with cells containing the ${ }^{14} \mathrm{C}(0)$ label and analyzed by alkaline $\mathrm{CsCl}$ as described in Methods. (B) Lymphocytes were treated with $50 \mathrm{~J} / \mathrm{m}^{2} \mathrm{UV}$ radiation, incubated for $3 \mathrm{~h}$ in $\alpha$-modified Eagle's medium with $10 \%$ fetal calf serum, and then permeabilized and incubated for $30 \mathrm{~min}$ in the reaction mix containing BrdUTP plus $\left[{ }^{3} \mathrm{H}\right] \mathrm{dTTP}$. The cells containing the ${ }^{3} \mathrm{H}(\mathrm{O})$ and density label were combined with the $\left[{ }^{14} \mathrm{C}\right]-$ $\mathrm{dThd}$ labeled cells $(\Theta)$ and analyzed in alkaline $\mathrm{CsCl}$ gradients. Density of cesium chloride $(\boldsymbol{\Delta})$.

A marked increase in poly(ADPR) synthesis also occurred when cells from each of the donors were treated with DNase under conditions which render the nuclear DNA accessible to DNase degradation $(4,20)$. In all cases, the DNase-responsive increase in poly(ADPR) synthesis was greater than the response to UV irradiation. Thus, resting, peripheral blood lymphocytes have a low level of poly(ADPR) synthesis which is stimulated by DNA-damaging treatments, such as UV irradiation, and markedly stimulated by treatment with DNase.

The question arose as to whether the DNase stimulation of poly(ADPR) synthesis could be used to determine whether poly(ADPR) synthesis occurs in response 
TABLE I

Synthesis of DNA and Poly(ADPR) by Normal Human

Lymphocytes in Response to UV Irradiation and

DNase Treatment

\begin{tabular}{|c|c|c|c|c|c|}
\hline \multirow[b]{2}{*}{ Donor } & \multicolumn{2}{|c|}{$\begin{array}{l}\text { DNA synthesis } \\
\text { incorporation } \\
{\left[{ }^{H} \mathrm{H}\right] \mathrm{dTMP}}\end{array}$} & \multicolumn{3}{|c|}{$\begin{array}{c}\text { Poly(ADPR) synthesis } \\
\left.\text { incorporation [ }{ }^{3} \mathrm{H}\right] \mathrm{ADPR}\end{array}$} \\
\hline & Control & UV & Control & UV & DNase \\
\hline & \multicolumn{2}{|c|}{$d p m / 10^{8}$ cells } & \multicolumn{3}{|c|}{$d p m / 10^{6}$ cells } \\
\hline 1 & 760 & 6,137 & 622 & 2,984 & 10,088 \\
\hline 2 & 959 & 8,950 & 1,077 & 4,017 & 12,504 \\
\hline 3 & 1,199 & 17,059 & 1,017 & 8,494 & 18,982 \\
\hline 4 & 2,743 & 14,853 & 687 & 4,583 & 10,856 \\
\hline 5 & 816 & 3,135 & 493 & 1,891 & 4,078 \\
\hline 6 & 1,015 & 6,078 & 560 & 2,671 & 6,507 \\
\hline 7 & 821 & 8,762 & 716 & 4,072 & 10,141 \\
\hline 8 & 2,036 & 19,313 & 1,640 & 5,213 & 12,239 \\
\hline 9 & 1,473 & 12,537 & 1,118 & 3,897 & 11,879 \\
\hline 10 & 2,105 & 15,864 & 996 & 3,990 & 6,405 \\
\hline 11 & 1,949 & 16,400 & 1,299 & 6,013 & 12,267 \\
\hline 12 & 2,051 & 13,622 & 723 & 4,012 & 10,651 \\
\hline
\end{tabular}

Human lymphocytes were prepared from 12 consecutive normal donors. They were suspended in PBS at $2 \times 10^{6}$ cells $/ \mathrm{ml}$ and UV irradiated with $50 \mathrm{~J} / \mathrm{m}^{2}$ as described in Methods. Cells were incubated at $37^{\circ} \mathrm{C}$ in $\alpha$-modified Eagle's medium with $10 \%$ serum for $3 \mathrm{~h}$ after irradiation. Control and irradiated cells were then permeabilized, and aliquots of $1 \times 10^{6}$ cells were used to measure synthesis of DNA and poly(ADPR). The DNase-responsive poly(ADPR) synthesis was measured with control cells that were permeabilized and then treated with $30 \mu \mathrm{g}$ DNase $/ 10^{6}$ cells in the final incubation system as described in Methods.

to DNA damage or to DNA repair synthesis. At the concentration of $300 \mu \mathrm{g} / \mathrm{ml}$ DNase used to produce maximal stimulation of poly(ADPR) synthesis, the assay could not detect DNA repair synthesis because any newly synthesized DNA would be degraded by the high concentration of enzyme. This is shown in Table II for the UV-irradiated cells, where the addition of $300 \mu \mathrm{g} / \mathrm{ml}$ of DNase caused a marked decrease in the detectable level of DNA synthesis. At lower concentrations of 5 or $10 \mu \mathrm{g} / \mathrm{ml}$, added DNase did not interfere with the ability to detect UV-induced DNA repair. When control, unirradiated cells, were treated with DNase at $5 \mu \mathrm{g} / \mathrm{ml}$ there was no significant change in synthesis of DNA or poly(ADPR). When the control cells were treated with $10 \mu \mathrm{g} / \mathrm{ml}$ DNase there was an increase in synthesis of both DNA and poly(ADPR). Because this represents an abrupt increase in unscheduled DNA synthesis, it is probable that this represents DNA repair and(or) end addition in response to the DNase treatment in these resting lymphocytes. These results are in agreement with our previous studies showing that poly(ADPR) synthesis increases with in-
TABLE II

Synthesis of DNA and Poly(ADPR) by Normal Human Lymphocytes in Response to DNase Treatment

\begin{tabular}{ccc}
\hline Treatment & $\begin{array}{c}\text { DNA synthesis } \\
\text { incorporation } \\
{\left[{ }^{3} \text { H]dTMP }\right.}\end{array}$ & $\begin{array}{c}\text { Poly(ADPR) synthesis } \\
\text { incorporation } \\
\text { ['H]ADPR }\end{array}$ \\
\hline Control cells & \multicolumn{2}{c}{$d p m / 10^{6}$ cells } \\
+DNase, $300 \mu \mathrm{g} / \mathrm{ml}$ & 2,302 & 825 \\
+DNase, $10 \mu \mathrm{g} / \mathrm{ml}$ & 1,046 & 11,159 \\
+DNase, $5 \mu \mathrm{g} / \mathrm{ml}$ & 6,020 & 2,254 \\
UV-irradiated $\mathrm{cells}$ & 2,717 & 1,068 \\
+DNase, $300 \mu \mathrm{g} / \mathrm{ml}$ & 6,344 & 3,318 \\
+DNase, $10 \mu \mathrm{g} / \mathrm{ml}$ & 1,521 & 12,397 \\
+ DNase, $5 \mu \mathrm{g} / \mathrm{ml}$ & 9,781 & 5,210 \\
\hline
\end{tabular}

Lymphocytes were prepared and UV irradiated with $50 \mathrm{~J} / \mathrm{m}^{2}$. Control and irradiated cells were then incubated at $1 \times 10^{6} / \mathrm{ml}$ for $3 \mathrm{~h}$ at $37^{\circ} \mathrm{C}$ in complete medium. Cells were permeabilized and then incubated with the appropriate reaction mix to measure synthesis of DNA or poly(ADPR). All reactions contained a final concentration of $0.05 \%$ Triton X-100. DNase was present in the final reaction systems at the indicated concentrations.

creasing concentrations of DNase. They are also in agreement with the recent studies by Smith and Hanawalt (21) in which similar, low concentrations of DNase promoted small increases in DNA synthesis in preparations of isolated nuclei. These studies demonstrate that the lowest concentration of added DNase, which effectively stimulates poly(ADPR) synthesis, also results in the concurrent stimulation of DNA repair-type synthesis. Thus, these studies again demonstrate the association of poly(ADPR) synthesis with DNA damage and repair; however, they do not differentiate whether poly(ADPR) synthesis is a consequence of DNA damage, DNA repair, or both.

We also investigated several other DNA-damaging agents for their abilities to stimulate the unscheduled synthesis of DNA and poly(ADPR). Table III shows that treatment with bleomycin, $N$-acetoxy-acetyl-aminofluorene, and $N$-methyl- $N^{\prime}$-nitro- $N$-nitrosoguanidine all stimulate synthesis of DNA and poly(ADPR). Table III also shows that the increase in synthesis of DNA and poly(ADPR) that follows treatment with DNA-damaging agents cannot be prevented by the presence of the protein-synthesis inhibitor cycloheximide at 50 or $100 \mu \mathrm{g} / \mathrm{ml}$. To confirm that the cycloheximide was in fact inhibiting protein synthesis in these cells, we measured the incorporation of $\left[{ }^{3} \mathrm{H}\right]$ leucine into protein by control and UV-irradiated cells incubated for $3 \mathrm{~h}$ in the presence or absence of cycloheximide. We also measured the levels of DNA and poly(ADPR) synthesis in these cycloheximide-treated cells. Table IV shows 
TABLE III

Synthesis of DNA and Poly(ADPR) by Normal Human

Lymphocytes in Response to DNA-Damaging Agents

\begin{tabular}{|c|c|c|}
\hline Treatment & $\begin{array}{l}\text { DNA synthesis } \\
\text { incorporation } \\
{\left[{ }^{3} \mathrm{H}\right] \mathrm{dTMP}}\end{array}$ & $\begin{array}{c}\text { Poly(ADPR) } \\
\text { synthesis } \\
\text { incorporation } \\
{\left[{ }^{3} \mathrm{H}\right] \mathrm{ADPR}}\end{array}$ \\
\hline & \multicolumn{2}{|c|}{$d p m / 10^{6}$ cells } \\
\hline \multicolumn{3}{|l|}{ Donor 1} \\
\hline Control & 760 & 622 \\
\hline $\mathrm{UV}, 50 \mathrm{~J} / \mathrm{m}^{2}$ & 6,137 & 2,984 \\
\hline Bleomycin, $20 \mu \mathrm{g} / \mathrm{ml}$ & 1,280 & 1,116 \\
\hline MNNG, $20 \mu \mathrm{g} / \mathrm{ml}$ & 3,589 & 10,278 \\
\hline NAAAF, $10 \mu \mathrm{g} / \mathrm{ml}$ & 3,778 & 3,174 \\
\hline \multicolumn{3}{|l|}{ Donor 2} \\
\hline Control & 959 & 1,077 \\
\hline $\begin{array}{l}\text { Control + cycloheximide, } \\
50 \mu \mathrm{g} / \mathrm{ml}\end{array}$ & 1,080 & 1,580 \\
\hline $\mathrm{UV}, 50 \mathrm{~J} / \mathrm{m}^{2}$ & 8,950 & 4,017 \\
\hline $\begin{array}{l}\text { UV, } 50 \mathrm{~J} / \mathrm{m}^{2}+\text { cycloheximide, } \\
50 \mu \mathrm{g} / \mathrm{ml}\end{array}$ & 8,971 & 4,142 \\
\hline Bleomycin, $20 \mu \mathrm{g} / \mathrm{ml}$ & 1,762 & 1,968 \\
\hline $\begin{array}{l}\text { Bleomycin, } 20 \mu \mathrm{g} / \mathrm{ml} \\
\quad+\text { cycloheximide, } 50 \mu \mathrm{g} / \mathrm{ml}\end{array}$ & 4,004 & 5,028 \\
\hline $\mathrm{MNNG}, 20 \mu \mathrm{g} / \mathrm{ml}$ & 5,787 & 15,038 \\
\hline $\begin{array}{l}\text { MNNG, } 20 \mu \mathrm{g} / \mathrm{ml}+\text { cyclohexi- } \\
\text { mide, } 50 \mu \mathrm{g} / \mathrm{ml}\end{array}$ & 4,852 & 15,727 \\
\hline NAAAF, $10 \mu \mathrm{g} / \mathrm{ml}$ & 5,504 & 2,985 \\
\hline $\begin{array}{l}\text { NAAAF, } 10 \mu \mathrm{g} / \mathrm{ml}+\text { cyclo- } \\
\text { heximide, } 50 \mu \mathrm{g} / \mathrm{ml}\end{array}$ & 5,978 & 3,171 \\
\hline Donor 8 & & \\
\hline Control & 2,036 & 1,640 \\
\hline $\begin{array}{l}\text { Control + cycloheximide, } \\
100 \mu \mathrm{g} / \mathrm{ml}\end{array}$ & 2,523 & 3,470 \\
\hline $\mathrm{UV}, 50 \mathrm{~J} / \mathrm{m}^{2}$ & 19,313 & 5,213 \\
\hline $\begin{array}{l}\mathrm{UV}, 50 \mathrm{~J} / \mathrm{m}^{2}+\text { cycloheximide, } \\
100 \mu \mathrm{g} / \mathrm{ml}\end{array}$ & 21,834 & 6,638 \\
\hline
\end{tabular}

Normal human lymphocytes were suspended in PBS and UV irradiated as described in Methods or maintained in medium to which different agents were added directly. Experiments were conducted so that the time of UV irradiation was the same as drug addition. The final concentration of each drug in the incubation system is listed. For donors 2 and 8 , cycloheximide was added to the indicated cultures just before addition of the other drugs or $7 \mathrm{~min}$ after UV irradiation. Control and treated cells were incubated at $37^{\circ} \mathrm{C}$ for $3 \mathrm{~h}$, then permeabilized and used to measure synthesis of DNA and poly(ADPR). MNNG, $N$-methyl- $N^{\prime}$-nitro- $N$ nitrosoguanide. NAAAF, $N$-acetoxy-acetyl aminofluorene.

that in control, unirradiated cells, the presence of 50 or $100 \mu \mathrm{g} / \mathrm{ml}$ cycloheximide inhibited protein synthesis by 97 or $98 \%$, respectively. UV irradiation caused a $70 \%$ decrease in the rate of protein synthesis. The residual protein synthesis in the UV-irradiated cells was inhibited by $96 \%$ in the presence of cycloheximide at 50 or $100 \mu \mathrm{g} / \mathrm{ml}$. Because doubling the concentration of cycloheximide from 50 to $100 \mu \mathrm{g} / \mathrm{ml}$ did not result in a
TABLE IV

Effect of Cycloheximide on Synthesis of Protein, DNA, and Poly(ADPR) in Resting and UV-Irradiated Human Lymphocytes

\begin{tabular}{|c|c|c|c|}
\hline Treatment & $\begin{array}{c}\text { Protein } \\
\text { synthesis } \\
\text { incorporation } \\
\left.{ }^{3} \mathrm{H}\right] \text { leucine }\end{array}$ & $\begin{array}{c}\text { DNA synthesis } \\
\text { incorporation } \\
{\left[{ }^{3} \mathrm{H}\right] \mathrm{dTMP}}\end{array}$ & $\begin{array}{c}\text { Poly(ADPR) } \\
\text { synthesis } \\
\text { incorporation } \\
\left.\text { ( }{ }^{3} \mathrm{H}\right] \mathrm{ADPR}\end{array}$ \\
\hline & $\begin{array}{l}d p m \times 0.01 / 10^{6} \\
\quad \text { cells } / 3 \mathrm{~h}\end{array}$ & $d p m / 10^{6}$ cells & $d p m / 10^{6}$ cells \\
\hline \multirow{3}{*}{$\begin{array}{l}\text { Unirradiated cells } \\
\text { +Cycloheximide, } \\
50 \mu \mathrm{g} / \mathrm{ml} \\
\text { +Cycloheximide, } \\
100 \mu \mathrm{g} / \mathrm{ml}\end{array}$} & 4,269 & 2,815 & 684 \\
\hline & 119 & 1,270 & 939 \\
\hline & 78 & 2,128 & 1,239 \\
\hline \multirow{3}{*}{$\begin{array}{l}\text { UV-irradiated cells } \\
\text { +Cycloheximide, } \\
50 \mu \mathrm{g} / \mathrm{ml} \\
+ \text { Cycloheximide } \\
100 \mu \mathrm{g} / \mathrm{ml}\end{array}$} & 1,303 & 13,900 & 5,353 \\
\hline & 50 & 18,628 & 6,239 \\
\hline & 42 & 16,415 & 5,755 \\
\hline
\end{tabular}

Lymphocytes were prepared and UV irradiated with $50 \mathrm{~J} / \mathrm{m}^{2}$ as described in Methods. Irradiated and unirradiated cells were suspended at $1 \times 10^{6} / \mathrm{ml}$ in leucine-deficient medium, immediately treated with indicated concentrations of cycloheximide, and then incubated for $3 \mathrm{~h}$ at $37^{\circ} \mathrm{C}$. Protein synthesis was measured in aliquots of cells incubated for $3 \mathrm{~h}$ in the presence of $\left[{ }^{3} \mathrm{H}\right]$ leucine $(25 \mu \mathrm{Ci} / \mathrm{ml})$. In these experiments, $\left[{ }^{3} \mathrm{H}\right]$ leucine and cycloheximide were added simultaneously. At the end of the 3-h incubation period, aliquots of cells incubated in the absence of $\left[{ }^{3} \mathrm{H}\right]$ leucine, were permeabilized and used to measure synthesis of DNA and poly(ADPR) as described in Methods.

significant increase in inhibition of protein synthesis, no higher concentrations were tested. This inhibition of protein synthesis with cycloheximide did not prevent the increase in DNA repair or poly(ADPR) synthesis after UV irradiation. Thus, the increased synthesis of DNA and poly(ADPR) that occurs in response to DNA damage appears to take place with preexisting enzymes. An additional feature of interest, which we have observed in several experiments but have not yet explained, is that whereas bleomycin treatment causes a relatively small increase in synthesis of DNA and poly(ADPR), incubation of bleomycin-treated cells with cycloheximide results in an even greater stimulation of polymer synthesis.

\section{DISCUSSION}

In these studies we used permeabilized human lymphocytes to measure the unscheduled synthesis of DNA and poly(ADPR) that follows treatment with UV radiation and other DNA-damaging agents. The BrdUTP density-shift experiments along with our previous studies demonstrate that the permeable cell system can 
be used to measure either the replicative or repair mode of DNA synthesis $(12,13,16)$. More importantly, these studies demonstrate that the permeable cell system can be used to detect the synthesis of DNA and poly(ADPR) which occurs in response to several different types of DNA damage. Such a system could be useful as a rapid test to determine whether suspect agents are capable of causing DNA damage in normal human cells. It may also be possible to use this system to evaluate the abilities of different individuals to respond to the effects of DNA-damaging agents.

These studies demonstrate that poly(ADPR) synthesis increases in association with the increase in DNA repair synthesis that occurs in normal human lymphocytes in response to treatment with DNA-damaging agents. On the basis of these studies, it is impossible to determine whether a causal relation exists between DNA repair and poly(ADPR) synthesis. However, it does seem clear that both are consequences, either directly or indirectly, of DNA damage. We have previously shown that poly(ADPR) synthesis increased when replicative DNA synthesis was suppressed in various ways in $L$ cells and Chinese hamster ovary (CHO) cells $(22,23)$, and that suppression of replicative DNA synthesis in CHO cells was associated with the development of DNA strand breaks as examined on alkaline sucrose gradients. ${ }^{2}$ Thus the increase in poly(ADPR) synthesis that occurs with suppression of DNA synthesis in CHO cells may also be associated with a response to DNA damage.

The function of poly(ADPR), if any, in DNA repair remains unknown. Studies with extracts of cells from patients with defects in DNA repair have shown that, in some cases, these extracts are capable of repairing UV damage in purified DNA but not in their own chromatin (24). These studies have led to the speculation that an accessibility factor may be required to alter the chromatin structure so that damaged regions of DNA can become accessible to repair enzymes $(3,25)$. Poly(ADPR) is a good candidate for such a factor as it is a polyanion which, upon attachment to histones or other chromosomal proteins, could alter their association with DNA and allow for exposure of regions of damaged DNA.

Poly(ADPR) polymerase also has several features that would be advantageous for an enzyme involved in DNA repair processes. First, it exists tightly bound to chromatin $(1,2)$ so it is in an appropriate location to respond to DNA damage. Second, upon challenge with DNase, there is a marked increase in poly(ADPR) polymerase activity in all cell types that we have examined,

\footnotetext{
${ }^{2}$ Berger, N. A., S. J. Petzold, and S. J. Berger. 1979. Association of poly(ADPRibose) synthesis with cessation of DNA synthesis and DNA fragmentation. Biochim. Biophys. Acta. In press.
}

including human lymphocytes, HeLa cells, $\mathrm{CHO}$ cells, $\mathrm{L}$ cells, human fibroblasts, L1210 cells, and murine erythroleukemia cells $(3,4,12,13)$. There is also a marked increase in the DNase-responsive activity in all phases of the cell cycle and in all stages of cell growth $(22,23)$. Thus, these cells all appear to contain a large reserve of poly(ADPR) polymerase capable of responding to DNA damage. As shown in this study, the enzyme response is not dependent upon new protein synthesis but increases abruptly after DNA damage even in the presence of protein-synthesis inhibitors. The presence, in the chromatin, of a reserve quantity of enzyme that can respond to DNA damage without requiring new protein synthesis, would appear to have valuable features for an enzyme involved in DNA repair.

It is interesting to note that many cell types show an increased ability to repair DNA damage when they are held in plateau or density-dependent inhibition (27). As noted above, when L or CHO cells are in plateau phase they show a spontaneously increased level of poly(ADPR) synthesis $(22,23)$. Thus, it is possible that these cells have an elevated level of poly(ADP ribosylated) chromatin proteins which allows repair enzymes more rapid access to regions of damaged DNA and accounts in part for the greater ability of these cells to repair damaged DNA. More studies are clearly indicated to determine the role of poly(ADPR) synthesis in DNA repair and also to determine whether cells from patients with disorders of DNA repair have any defects in poly(ADPR) synthesis.

\section{ACKNOWLEDGMENTS}

We thank Dr. Stanley T. Crooke of Bristol Laboratories for the bleomycin.

This work was supported in part by grants from the National Leukemia Association, Inc., Garden City, N. Y., The Jewish Hospital of St. Louis, and grant number 1 R01 CA24986-01 from the National Cancer Institute of the Department of Health, Education, and Welfare.

\section{REFERENCES}

1. Hayaishi, O., and K. Ueda. 1977. Poly(ADPRibose) and ADP-ribosylation of proteins. Annu. Rev. Biochem. 46: 95-116.

2. Ueda, K., R. H. Reeder, T. Honjo, Y. Nishizuka, and O. Hayaishi. 1968. Poly(adenosine diphosphate ribose) synthesis associated with chromatin. Biochem. Biophys. Res. Commun. 31: 379-385.

3. Miller, E. G. 1975. Stimulation of nuclear poly(adenosine diphosphate ribose) polymerase activity from HeLa cells by endonucleases. Biochim. Biophys. Acta. 395: 191-200.

4. Berger, N. A., G. Weber, and A. S. Kaichi. 1978. Characterization and comparison of poly(adenosine diphospho ribose) synthesis and DNA synthesis in nucleotide permeable cells. Biochim. Biophys. Acta. 519: 87-104.

5. Miller, E. G. 1976. Stimulation of poly(adenosine diphosphate ribose) polymerase activity by bleomycin. Fed. Proc. 36: 906. (Abstr.)

6. Davies, M. J., S. Shall, and C. J. Skidmore. 1977. Poly- 
(adenosine diphosphate ribose) polymerase and deoxyribonucleic acid damage. Biochem. Soc. Trans. 5: 949-950.

7. Benjamin, R. C., and D. M. Gill. 1978. A possible role for poly ADP-Ribose in the repair of DNA. J. Supramolec. Struct. 2(Suppl.): 74. (Abstr.)

8. Jacobson, M. K., and E. L. Jacobson. 1978. Alteration of NAD metabolism associated with carcinogen-induced DNA damage. J. Supramolec. Struct. 2(Suppl.): 74. (Abstr.)

9. Smulson, M. E., P. Schein, D. W. Mullins, Jr., and S. Sudhakar. 1977. A putative role for nicotinamide adenine dinucleotide-promoted nuclear protein modification in the antitumor activity of $N$-methyl- $N$-nitrosourea. Cancer Res. 37: 3006-3012.

10. Regan, J. D., and R. B. Setlow. 1974. Two forms of repair in the DNA of human cells damaged by chemical carcinogens and mutagens. Cancer Res. 34: 3318-3325.

11. Suzuki, H., K. Nagai, E. Akutsu, H. Yamaki, N. Tanaka, and $\mathrm{H}$. Umezawa. 1970. On the mechanism of action of bleomycin. Strand scission of DNA caused by bleomycin and its binding to DNA in vitro. J. Antibiot. (Tokyo). 23: 473-480.

12. Berger, N. A., J. W. Adams, G. W. Sikorski, S. J. Petzold, and W. T. Shearer. 1978. Synthesis of DNA and poly (adenosine diphosphate ribose) in normal and chronic lymphocytic leukemia lymphocytes. J. Clin. Invest. 62: $111-118$.

13. Berger, N. A., and E. S. Johnson. 1976. DNA synthesis in permeabilized mouse L cells. Biochim. Biophys. Acta. 425: $1-17$.

14. Mendelsohn, J. S., S. A. Skinner, and S. Kornfeld. 1971 The rapid induction by phytohemagglutinin of increased $\alpha$ aminoisobutyric acid uptake by lymphocytes. J. Clin. Invest. 50: 818-826.

15. Kornfeld, R., W. T. Gregory, and S. A. Kornfeld. 1972. Red kidney bean (Phaseolus Vulgaris) phytohemagglutinin. Methods Enzymol. 28: 344-349.

16. Berger, N. A., S. J. Petzold, and E. S. Johnson. 1977. High molecular weight DNA intermediates synthesized by permeabilized L cells. Biochim. Biophys. Acta. 478: 44-58.
17. Painter, R. B., and J. E. Cleaver. 1969. Repair replication, unscheduled DNA synthesis and the repair of mammalian DNA. Radiat. Res. 37: 451-466.

18. Yoffey, J. M., G. C. B. Winter, D. G. Osmond, and E. S. Meek. 1965. Morphological studies in culture of human leucocytes with phytohemagglutinin. Br.J.Haematol. 11 : $488-497$.

19. Masker, W. E., and P. C. Hanawalt. 1973. Ultravioletstimulated DNA synthesis in toluenized Escherichia Coli deficient in DNA polymerase I. Proc. Natl. Acad. Sci. U. S. A. 70: 129-133.

20. Berger, N. A., W. P. Erickson, and G. Weber. 1976. Histone inhibition of DNA synthesis in eukaryotic cells permeable to macromolecules. Biochim. Biophys. Acta. 447: 65-75.

21. Smith C. A., and P. C. Hanawalt. 1978. Phage T4 endonuclease $\mathrm{V}$ stimulates DNA repair replication in isolated nuclei from ultraviolet-irradiated human cells, including xeroderma pigmentosum fibroblasts. Proc. Natl. Acad.Sci. U. S. A. 75: 2598-2602.

22. Berger, N. A., G. Weber, A. S. Kaichi, and S. J. Petzold. 1978. Relation of poly(adenosine diphosphoribose) synthesis to DNA synthesis and cell growth. Biochim. Biophys. Acta. 519: 105-117.

23. Berger, N. A., A. S. Kaichi, P. G. Steward, R. R. Klevecz, G. L. Forrest, and S. D. Gross. 1978. Synthesis of poly (adenosine diphosphate ribose) in synchronized Chinese hamster cells. Exp. Cell Res. 117: 127-135.

24. Mortelmans, K., E. C. Friedberg, H. Slor, G. Thomas, and J. E. Cleaver. 1976. Defective thymine dimer excision by cell-free extracts of xeroderma pigmentosum cells. Proc. Natl. Acad. Sci. U. S. A. 73: 2757-2761.

25. Cleaver, J. E. 1978. Xeroderma pigmentosum. In The Metabolic Basis of Inherited Disease. 4th Edition. J. B. Stanbury, J. B. Wyngaarden, and D. S. Fredrickson, editors. McGraw-Hill Book Co., New York. 1072-1095.

26. Hahan, G. M. 1975. Radiation and chemically induced potentially lethal lesions in noncycling mammalian cells: recovery analysis in terms of X-ray- and ultraviolet-likesystems. Radiat. Res. 64: 533-545. 